\title{
IZOBRAŽEVALNI PROGRAM "UŽU IZZIVI PODEŽELJA« V LUČI SOCIALNEGA KAPITALA
}

Mag. Eva

Mermolja

Ljudska univerza

Ajdovščina

\section{POVZETEK}

Avtorica v prispevku preučuje povezave med neformalnim izobraževanjem odraslih in razvojem socialnega kapitala $v$ lokalnem okolju. Ugotavlja, kako izobraževalni program za odrasle UŽU Izzivi podeželja prispeva k ustvarjanju socialnega kapitala na podeželju. V ta namen najprej opredeli osnovno terminologijo: definira podeželje, socialni kapital in predstavi izobraževalni program UŽU Izzivi podeželja.

Empirični del temelji na kvalitativni analizi. Na primeru neformalnega izobraževalnega programa za odrasle UŽU Izzivi podeželja je bila izvedena primerjalna analiza med skupino oseb, ki niso bile vključene v program UŽU Izzivi podeželja, in udeleženci programa. Pokazalo se je, da obstajajo nekatere razlike glede posameznih elementov socialnega kapitala. Največje razlike se kažejo v socialnih omrežjih in normah recipročnosti.

Ključne besede: socialni kapital, izobraževanje odraslih, neformalno izobraževanje odraslih, UŽU Izzivi podeželja

\section{THE ADULT EDUCATIONAL PROGRAMME "CHALLENGES OF RURAL AREAS” IN THE LIGHT OF SOCIAL CAPITAL - ABSTRACT}

In the article the author discusses the connection between informal adult education and the development of social capital in a local environment. She proceeds to analyse how the adult education programme "Training for Success in Life - Challenges of Rural Areas" contributes to the development of social capital in some rural areas. For this purpose she defines the key terms: rural area and social capital, and presents the adult education programme "Training for Life Success - Challenges of Rural Areas".

The empirical part is based on a qualitative analysis. The programme "Challenges of Rural Areas (CRA)" was used as a basis for a comparative analysis of two groups, the participants of the CRA programme and a group consisting of people who did not participate. The analysis revealed certain differences with regard to specific elements of social capital. The greatest difference was observed in connection with social networks and the norms of reciprocity.

Keywords: social capital, adult education, informal adult education, Training for Life Success - Challenges of Rural Areas

UDK: $374.7: 316$

\section{UVOD}

Koncept socialnega kapitala je eden od pomembnejših v sodobnih družboslovnih razmišljanjih, ugotavljajo različni raziskovalci (Rončević, 2003: 5; Tomšič, 2003: 33; Kump, 2003: 148). Izkazal se je kot izjemno relevanten na različnih področjih družbenega delovanja: od politike in državljanstva prek organizacij in podjetništva do izobraževanja (Adam in drugi, 2003: 2). V primerjavi s številnimi zahodnoevropskimi državami je socialni kapital v Sloveniji skromen, njegov potencial pa neizkoriščen. Če želimo spodbujati razvoj socialnega kapitala, se moramo osredotočiti na dejavnike, ki vplivajo na posamezne vidike tega koncepta. V pričujoči študiji smo se osredotočili na razvojne možnosti socialnega kapitala znotraj izobraževanja, pri čemer smo se omejili na izobraževanje odraslih in se usmerili na slovensko podeželje. Povezave med neformalnim izobraževanjem odraslih in 
razvojem socialnega kapitala smo iskali na primeru izobraževalnega programa za odrasle »Usposabljanje za življenjsko uspešnost Izzivi podeželja (UŽU IP)«.

\section{Opredelitev podeželja}

Za slovensko državo je značilen podeželski značaj, kot ugotavljajo različni avtorji (Pelc, 2002; Kovačič in drugi, 2000), vendar pa nimamo enotne opredelitve podeželja, zato tudi ni enotnih podatkov o deležu površine podeželja. V najbolj splošnem pomenu besede podeželje pomeni prostor in način življenja zunaj mest.

Podeželje danes izgublja tradicionalno vlogo območja za pridelavo hrane, ki jo je nekoč imelo. Vse bolj postaja zgolj prostor bivanja in dela ljudi, ki se ukvarjajo z različnimi nekmetijskimi dejavnostmi (Barbič, 2005). Srečujemo se s procesom protiurbanizacije, h kateremu zagotovo prispevajo zavedanje o kakovosti življenja na podeželju ter razvita prometna infrastruktura in sodobni razvoj tehnologije. Zaradi medsebojnega prepletanja urbanega in ruralnega načina življenja ni več ostre ločnice med njima, vseeno pa je še vedno mogoče jasno prepoznati dva življenjska vzorca: mestnega in podeželskega. Na podeželju prevladujejo naravne prvine in primarna raba prostora ter intenzivnejši socialni stiki, mesto pa zaznamujeta zgostitev grajenih struktur in prevladujoča individualizacija na socialnem področju (Kovačič in drugi, 2000: 17).

\section{Socialni kapital}

Med raziskovalci socialnega kapitala ni popolnega soglasja o splošni definiciji in merskih značilnostih, kar se kaže $\mathrm{v}$ zanimivi strukturi bogatega obsega del, ki ta koncept uporabljajo na različne načine. Navkljub raz- likam pri definiranju socialnega kapitala pa najdemo enotnost avtorjev v tem, da se koncept socialnega kapitala nanaša na omrežja, norme recipročnosti in zaupanje. Vsem definicijam je skupna osredotočenost na družbene vezi, ki prinašajo produktivne koristi. V ospredje postavljajo družbeno povezanost, odnose recipročnosti, relacije in zaupanje (Lenarčič, 2010).

Odnosi med komponentami socialnega kapitala so precej kompleksni (Adam in drugi, 2001), zaznamuje jih visoka stopnja medsebojne povezanosti oziroma soodvisnosti, ki je prvi pogoj za obstoj socialnega kapitala. Znotraj širokega spektra komponent so se kot temeljne uveljavile zaupanje, norme recipročnosti in socialna omrežja. Nanje smo se omejili tudi v našem prispevku.

Že iz problema definiranja koncepta socialnega kapitala in kompleksnosti samega koncepta izhajajo težave, povezane $\mathrm{z}$ njegovo operacionalizacijo in merjenjem. Posledično se srečujemo z vrsto operacionalizacij in meritev. Mi smo se pri merjenju socialnega kapitala naslonili na Narayanovo in Cassidyjevo (2001) dimenzioniranje socialnega kapitala. Ta dva avtorja uporabita za merjenje socialnega kapitala več spremenljivk, in sicer značilnosti skupin, posplošene norme, bližino, povezanost soseske, prostovoljstvo in zaupanje.

Pri klasifikaciji socialnega kapitala se je uveljavilo razlikovanje med vezivnim (bonding) in premostitvenim (bridging) socialnim kapitalom, ki sta ga po ugotovitvah Putnama (2000) vpeljala Gittel in Vidal (1998). Vezivni socialni kapital se pojavlja na individualni ravni in poudarja koristi, ki jih ima posameznik od vključenosti v neko skupino ali širše medsebojne odnose, kot so družina, drugo sorodstvo, verske skupnosti ipd. Zanj so 
značilne močne vezi, ki delujejo kot omrežja, ki se vzpostavijo kot medij za uresničitev posameznikovih interesov. Ta vidik socialnega kapitala temelji na gostem omrežju, ki integrira posamezno skupino. Krepi posameznikovo identifikacijo s skupino, organizacijo, skupinsko lojalnost in medsebojno sodelovanje in je zato zelo produktiven (Adam in drugi, 2003). Putnam (2000) za vezivni socialni kapital trdi, da krepi homogenost in ga opredeli kot vezi med enako mislečimi posamezniki. Ta vrsta kapitala je značilna za tradicionalne družbe, v katerih ljudje veliko bolj zaupajo krvnim sorodnikom kot pa institucijam (Vehovar, 2009). Na drugi strani pa imamo v visokorazvitih družbah visoko raven zaupanja $\mathrm{v}$ soljudi in institucionalno okolje države. Tu imamo opraviti z visoko ravnjo premostitvenega kapitala, ki ga Putnam (2000) vidi kot pospeševalca družbene vključenosti. Povezuje ga s šibkimi vezmi in manjšim zaupanjem, večjo nevarnostjo kršitve norm in večjo instrumentalnostjo odnosov $\mathrm{v}$ omrežju. Zato je tukaj toliko nujnejše učinkovito delovanje institucij, pravne države in formalnega nadzora. V takem okolju so ljudje bolj pripravljeni zaupati drug drugemu. Ta vrsta socialnega kapitala sloni na redkih omrežjih in izkoriščanju strukturnih lukenj. Zaradi tega obstaja večja verjetnost za povezavo med heterogenimi posamezniki, kar ima z vidika medsebojnega sodelovanja in učenja praviloma pozitivne učinke. Premostitveni kapital tako daje poudarek posameznikovim koristim, pri katerih pozitivne učinke socialnega kapitala uživa celotna skupnost.

\section{PROGRAM USPOSABLJANIA ZA ŽIVLJENISKO USPEŠNOST IZZIVI PODEŽELJA}

Program »Usposabljanje za življenjsko uspešnost Izzivi podeželja« (v nadaljevanju UŽU
IP) je nastal ob podpori ministrstva za šolstvo in šport ter $\mathrm{v}$ sodelovanju Zveze ljudskih univerz Slovenije in Andragoškega centra Slovenije. Namenjen je manj izobraženim odraslim (deset ali manj let šolanja), pretežno prebivalcem podeželja, ki »so motivirani za pridobitev temeljnih spretnosti in novih znanj, za izboljšanje svojega ekonomskega in socialnega položaja na podeželju ter za izvajanje dejavnosti na podeželju « (ministrstvo za šolstvo in šport RS, 2005).

Pri skupinah prebivalstva, ki imajo nižjo stopnjo formalne izobrazbe, pogosto opazimo, da so imeli slabe izkušnje $\mathrm{s}$ formalnim izobraževanjem, da Socialni kapital
v Sloveniji je
neizkoriscen. se težje prilagajajo hitrim spremembam in slabše prepoznavajo lastne potenciale. Primanjkuje jim spretnosti v komunikaciji, iskanju in izbiri informacij in na splošno pri dejavnem vključevanju v širšo družbeno skupnost. Glavni cilj programa je, da udeleženci pridobijo temeljna znanja in spretnosti, s katerimi bodo laže prepoznavali in vrednotili lastne potenciale ter možnosti podeželskega okolja za izvajanje različnih dejavnosti, z namenom večje samostojnosti ter izboljšanja svojega ekonomskega in socialnega položaja. Namen programa je tudi pridobivanje socialnih spretnosti in usposabljanje za vseživljenjsko učenje ter aktivno državljanstvo, motiviranje udeležencev za pridobivanje novih znanj za izvajanje dejavnosti na podeželju pa tudi spodbujanje udeležencev k skrbi za trajnostni razvoj podeželja (ministrstvo za šolstvo in šport RS, 2005).

Program traja 120 ur (predvidoma se izpelje $\mathrm{v}$ treh mesecih) in poteka $\mathrm{v}$ obliki projektnega učenja $v$ skupinah od 12 do 16 udeležencev. Delo v skupini sočasno vodita dva usposobljena učitelja, ki program izvajata $\mathrm{v}$ 
okviru izvajalske organizacije za izobraževanje odraslih. Program sofinancirata ministrstvo za izobraževanje, znanost, kulturo in šport in Evropski socialni sklad, zato je za udeležence brezplačen.

\section{METODOLOGIJA}

\section{Opredelitev raziskovalnega problema}

V raziskavi nas je zanimalo, kakšne so povezave med neformalnim izobraževanjem odraslih in razvojem socialnega kapitala. To smo preučevali na primeru programa UŽU Izzivi podeželja. Zanimalo nas je, kako program UŽU IP pripomore k razvoju socialnega kapitala na podeželju. Ugotoviti smo želeli, ali je prišlo do kakšnih premikov v posameznih elementih socialnega kapitala: dvigu ravni zaupanja, generalizirani recipročnosti in $\mathrm{V}$ socialnih omrežjih (velikost omrežij, odprta omrežja šibkih/zaprta omrežja močnih vezi, krepitev, poglobljenost, obseg socialnih vezi).

Iskali smo povezave med ustvarjanjem socialnega kapitala in izobraževalnim programom. Zato smo izbrali naslednje elemente, ki označujejo izobraževalni program: dostopnost, organizacija in izvedba, cilji, vsebine, učne metode, ciljna skupina, sodelovanje $\mathrm{z}$ institucijo.

$\mathrm{Na}$ podlagi zbranih podatkov smo sklepali na posamezne vrste socialnega kapitala (vezivni/premostitveni), s katerimi se srečujemo na podeželju, predvsem pa, kako na pojav teh zvrsti vpliva neformalno izobraževanje.

\section{Raziskovalna vprašanja}

Naše glavno raziskovalno vprašanje je bilo: Kako lahko neformalno izobraževanje odraslih povežemo z razvojem socialnega kapitala v lokalnem okolju?
Postavili smo si tudi dve podvprašanji:

Kako izobraževalni program za odrasle UŽU IP prispeva $\mathrm{k}$ razvoju socialnega kapitala na podeželju?

Kateri so tisti elementi programa UŽU IP, ki jih lahko povežemo z razvojem socialnega kapitala?

\section{Vrsta raziskave, raziskovalna metoda, zbiranje podatkov}

Glede na namen naše raziskave smo izbrali fenomenološko metodo in se omejili na kvalitativne raziskovalne metode. Gre za študijo primera, preučevani primer pa je bil neformalni izobraževalni program za odrasle UŽU IP, ki ga je v letih 2009, 2010 in 2011 v treh vaseh (Dobravlje, Batuje in Lokavec) izvajala Ljudska univerza Ajdovščina.

Uporabili smo kvalitativne podatke iz primarnih virov, in sicer daljših polstrukturiranih ustnih intervjujev. V raziskavi smo uporabili primerjalno (komparativno) metodo: primerjali smo podatke iz intervjujev z udeleženci programa UŽU IP in z ljudmi, ki niso bili vključeni v program in ne živijo $v$ vaseh, kjer se je program izvajal. $\mathrm{V}$ primerjavi smo iskali razlike med obema skupinama ter sklepali na povezavo med programom UŽU IP in razvojem socialnega kapitala. Podatke smo zbirali od januarja do februarja 2012 z vprašalnikom, ki smo ga sami oblikovali.

Enote raziskave:

1. Skupina UŽU IP Dobravlje

2. Skupina UŽU IP Batuje

3. Skupina UŽU IP Lokavec

4. Osebe iz vasi, ki niso bile vključene v program UŽU IP

Izvedli smo 12 polstrukturiranih intervjujev, in sicer: 
- $\quad$ šest z udeleženci programa UŽU IP (dva iz Batuj, dva iz Lokavca in dva iz Dobravelj) in

- $\quad$ šest z osebami, ki sestavljajo ciljno skupino za program UŽU IP in ne prihajajo iz prej omenjenih vasi.

Pripravili smo dva različna vprašalnika, in sicer enega za udeležence programa IP, drugega pa za osebe, ki niso bile vključene $\mathrm{v}$ ta program in pomenijo ciljno skupino za ta program. Vprašalnika sta $v$ prvem delu enaka in zajemata vprašanja, ki se nanašajo na zaupanje, prostovoljstvo, preživljanje prostega časa in vključevanje $\mathrm{v}$ društva in druge skupine. Zajemajo torej ključne elemente socialnega kapitala. Drugi del vprašalnikov se razlikuje, in sicer se vprašanja nanašajo na vključevanje v izobraževanje, pri čemer udeleženci programa UŽU IP odgovarjajo tudi na vprašanja, ki se navezujejo na izvedbo programa in njihovo mnenje o vsebinah, pridobljenih znanjih ipd. Pridobili smo podatke o temeljnih elementih socialnega kapitala in iskali razlike med skupinama, torej med udeleženci programa UŽU IP in tistimi, ki niso bili vključeni v ta program. Iz analize podatkov smo sklepali na vpliv izobraževanja odraslih na razvoj socialnega kapitala.

V raziskavo smo vključili manjši, pogojno namenski slučajnostni vzorec. Iz vsake vasi, v kateri se je program izvajal, smo iz populacije 12 oseb/udeležencev na vas (skupaj torej 36) naključno izbrali po dve osebi/udeleženca (skupaj torej šest). Prav tako je bil pogojno namenski in slučajnostni vzorec šestih oseb, ki niso bile vključene $\mathrm{v}$ program. Naključno smo izbirali šest oseb, ki sestavljajo ciljno skupino za program UŽU IP (manj izobraženi prebivalci podeželja).

Zbrane podatke smo uredili s pomočjo odnosnega kodiranja in izrisom paradigmatskih modelov.

\section{PREDSTAVITEV PODATKOV}

\section{Udeleženci programa UŽU IP in njihovo doživljanje izobraževanja}

Program UŽU Izzivi podeželja je zaradi dostopnosti in zanimivih vsebin omogočil udeležencem spoznavanje novih ljudi in pridobivanje uporabnega znanja.

Za intervjuvance je zelo pomembno, da se je program izvajal v njihovi vasi, torej blizu doma. Večina udeležencev bi se le stežka odločila za vključitev v program, če bi se izvajal zunaj njihove vasi. Oddaljenost kraja izvajanja izobraževanja od njihovega doma jim pomeni predvsem časovno in finančno oviro, ena udeleženka kot oviro omenja prevoz in pravi: »... za iti v Ajdovščino moraš imet nekoga, da te pelje. Jaz avta ne vozim več ... Intervjuvanci pravijo, da bi se v program vključili, tudi če ne bi bil brezplačen, in bi bili pripravljeni plačati določen prispevek. $\mathrm{Z}$ vidika dostopnosti programa se je torej bolj kot brezplačnost pokazala kot pomembna izvedba bliže domu, torej v njihovi vasi.

Nekateri udeleženci so se že pred programom UŽU IP vključevali v krajša izobraževanja v okviru društev ali pri delodajalcu za potrebe dela. Večina udeležencev je v pogovoru kot poglavitni razlog za vključitev v program UŽU IP izrazila željo po druženju. Intervjuvanci pravijo, da so se $\mathrm{v}$ program UŽU IP vključili tudi zaradi želje po novem znanju, pri čemer mislijo predvsem na uporabna znanja za vsakdanje življenje in delo. Eden od udeležencev na vprašanje o razlogih za vključitev v program odgovarja: »Želja po čim več znanja. Gre za osnovna znanja, ki bi jih moral imeti vsak človek. Recimo cepljenje drevja, 80 odstotkov mladih tega ne zna - oni si morajo zdaj cepiti drevje, da bodo imeli kaj jesti.« 
Kot razlog za vključitev navajajo tudi zanimive vsebine in teme programa, pri tem pa $\mathrm{v}$ ospredje postavljajo računalništvo, tuje jezike, komunikacijo, kuharstvo, zdravo prehrano, zelišča, urejanje vrta in ustvarjalne delavnice. Predvsem pa so poudarjali uporabnost znanja za vsakdanje življenje, pri čemer še posebej omenjajo računalniška znanja, kjer navajajo možnost komunikacije in zniževanje stroškov.

Udeleženci, ki se pred programom UŽU IP niso vključevali $\mathrm{v}$ izobraževalne programe za odrasle, kot razlog za nevključevanje navajajo predvsem pomanjkanje časa in želje po izobraževanju. Večina vprašanih se je po končanem programu UŽU IP vključila še v druge izobraževalne programe, in sicer v javnoveljavni neformalni izobraževalni program UŽU Razgibajmo življenje z učenjem, NPK Socialna oskrbovalka na domu, tečaj Zdravje je naša odločitev, tečaje računalništva in tujih jezikov. Lahko torej trdimo, da je vključevanje v program UŽU IP vplivalo na vključevanje $\mathrm{v}$ druge izobraževalne programe za odrasle.

Na vprašanje o tem, kaj so pridobili s programom UŽU IP, intervjuvanci v večini navajajo pridobitev novih znanj in novih spoznanj, nekateri pa tudi osebnostno rast. Ena od udeleženk pravi: »Zdaj sem bolj odprta, gledaš drugače na svet, na ljudi. In nase ... Jaz sem bila s temi tečaji zelo zadovoljna, pridobiš nova znanja, nove prijatelje, nove pogovore, tudi samozavest ...«

Podobno razmišlja še ena udeleženka, ki odgovarja: »Predvsem to, da sem spoznala zelo dosti ljudi, dobrih ljudi ... da sem zrasla, drugače začneš gledati na življenje, malo bolj odprt, malo bolj pozitiven ...«

Tudi večina drugih intervjuvancev poudarja, da so v programu navezali nove stike in spoznali nove ljudi, ki so bodisi iz iste vasi bodisi iz drugih okoliških krajev. Med novimi poznanstvi navajajo tudi učitelje programa in organizatorje izobraževanja odraslih na ljudski univerzi. Ljudska univerza Ajdovščina je za večino tudi edina ustanova, s katero so udeleženci navezali stik in začeli uporabljati njene storitve. Le ena od vprašanih omenja še knjižnico, ki jo po končanju programa UŽU IP pogosteje obiskuje.

Udeležence programa UŽU IP smo spraševali tudi o bližini in povezanosti soseske. Razumevanja med prebivalci ne ocenjujejo niti kot odlično niti kot slabo, ampak nekje vmes. Poudarjajo pa, da se jim zdi pri povezanosti soseske pomembno poznavanje ljudi med sabo. Tu lahko vidimo močno povezavo med programom UŽU IP in povezanostjo soseske. Intervjuvanci pravijo, da so se zaradi programa med sabo bolje spoznali ali pa da so spoznali ljudi, ki jih prej niso poznali, kar lahko vpliva na večjo povezanost soseske. Nekateri poudarjajo tudi pomen izgradnje dvorane na vasi, ki je omogočila ljudem druženje in s tem vplivala na večji občutek pripadnosti vasi.

Tudi pri opredeljevanju glede posplošenih norm in zaupanja različnim skupinam ljudi intervjuvanci na prvo mesto postavljajo pomembnost poznavanja ljudi za večje zaupanje.

Kadar na splošno govorimo o zaupanju, intervjuvanci pravijo, da je treba biti do ljudi previden in da se zaupanje lahko vzpostavi šele, ko človeka nekoliko spoznaš. Nekateri govorijo o slabih izkušnjah, ki so krive za manjše zaupanje.

Intervjuvanci imajo različna mnenja o tem, ali so ljudje večinoma pripravljeni pomagati drugim oz. ali večinoma gledajo predvsem nase. Eden od intervjuvancev pravi, da je dalj časa povezan s skupino ljudi, ki si med sabo 
pomagajo, izmenjajo znanja in izkušnje, ter dodaja, da med njimi vlada zaupanje.

Večina intervjuvancev meni, da bi ljudje $\mathrm{v}$ glavnem ravnali pošteno in jih ne bi izkoristili, če bi dobili priložnost za to. Na tem mestu se lahko navežemo tudi na zaupanje, ki ga s temi odgovori izkazujejo vprašani. Poznavanje ljudi se še posebej pokaže kot pomembno pri vprašanju o zaupanju Slovencem, ljudem drugih narodnosti, ljudem v njihovi vasi in članom istih društev oziroma organizacij, ki jim pripadajo tudi sami. Pravijo, da morajo ljudi bolje poznati, če jim želijo zaupati, nekateri pa omenjajo slabe izkušnje, zaradi katerih so bolj previdni. Zato pa bolj zaupajo ljudem, ki pripadajo istim društvom, ker (kot pravijo) jih bolje poznajo. Intervjuvanci izkazujejo srednjo do močno raven zaupanja policiji, sodišču, sodnikom, vladnim službam in občinski upravi. Nezaupanje kažejo le do politikov, pri čemer nekateri omenjajo vpliv trenutnega dogajanja na politični sceni na njihovo mnenje.

Izkazalo se je, da so (razen enega) vsi vprašani vključeni v različna društva, pri tem pa omenjajo tako društvo upokojencev in invalidsko društvo ter univerzo za tretje življenjsko obdobje kot tudi športna, strokovna in kulturna društva. Za delovanje društev prispevajo letno članarino v znesku od 10 do 40 evrov.

Članstvo v društvih lahko tesno povežemo tudi s prostovoljstvom, vključevanjem v izobraževanje ter $\mathrm{z}$ vsakodnevnim druženjem.

Pri dejavnostih društva vprašani večinoma zelo aktivno sodelujejo. Narava sodelovanja je različna, večinoma pa se povezujejo tudi s prostovoljnim delom. Tu intervjuvanci navajajo sodelovanje pri čistilnih akcijah, organiziranju raznih praznovanj, razstav, predstavitvi vasi na sejmih in zbiranju sredstev za dobrodelne namene. Nekateri udeleženci se tudi vključujejo v krajša izobraževanja, predavanja in seminarje, organizirana v okviru društva.

Značilno je, da je članstvo društev izjemno heterogeno, saj se v isto društvo vključujejo ljudje različnih starosti, izobrazbene sestave, dohodkov in verske pripadnosti. Člani društev večinoma prihajajo iz različnih vasi in krajev. Vprašani poudarjajo tudi občutek pripadnosti skupini, ki člane povezuje tudi zunaj druženja v organizirani obliki znotraj društev. Vključenost $\mathrm{v}$ društvo pripomore $\mathrm{k}$ poznavanju večjega števila ljudi in oblikovanju širšega kroga prijateljev in znancev ter pomembno vpliva tudi na vsakodnevno druženje.

Udeleženci UŽU IP se v prostem času večinoma srečujejo s širokim krogom prijateljev in s sorodniki. Med prijatelji naštevajo družinske prijatelje, nekdanje sodelavce, sovaščane in člane različnih društev. Dva od intervjuvancev sta povedala, da $\mathrm{v}$ prostem času obiskujeta tudi bolnike na vasi, se z njimi pogovarjata in tako opravljata dobro delo. $\mathrm{V}$ tem primeru gre dejansko za ponujanje pomoči in lahko takšno dejavnost povežemo s prostovoljstvom.

Intervjuvance smo spraševali tudi o prostovoljstvu. Prostovoljno delo smo že povezali z dejavnostmi znotraj društev in prostočasnimi dejavnostmi. Zanimalo pa nas je tudi, kaj vprašani menijo o pripravljenosti ljudi pomagati pri skupnostnih dejavnostih. Intervjuvanci pravijo, da so ljudje pripravljeni prostovoljno pomagati pri skupnostnih dejavnostih, če vidijo smiselnost teh dejavnosti. Vprašanim se zdi, da se ljudje pogosto vključujejo v različne skupinske akcije, kot so denimo čistilne, pri čemer se zdi, da vedno sodelujejo eni in isti. Krepitev prostovoljstva na vasi pripisujejo tudi društvom, ki so v zadnjem času vse bolj dejavna.

Intervjuvanci so večinoma zelo kritični do tistih, ki ne sodelujejo pri skupnostnih 
dejavnostih. Večina jih tudi meni, da bi lahko nekateri prispevali veliko več, medtem ko nekateri prispevajo še preveč.

Udeleženci programa UŽU IP so v povprečju tudi sami izredno dejavni kot prostovoljci in tudi sodelujejo pri prostovoljnih dejavnostih društev in krajevne skupnosti.

V odgovorih na vprašanja o politični participaciji nismo našli povezav s preostalimi kate- gorijami. Vsi udeleženci so se udeležili tako državnozborskih kot lokalnih volitev. Razen enega udeleženca, ki je podpisal peticijo, ni nihče protestiral proti državnim ukrepom ali kot kandidat sodeloval na volitvah.

\section{Skupina, ki ni bila vključena v program}

Intervjuvanci se po večini ne vključujejo v izobraževanje niti v društva in tudi ne opravljajo prostovoljnega dela. V prostem času pa se

Slika 1: Paradigmatski model (udeleženci UŽU IP) usposabljanja

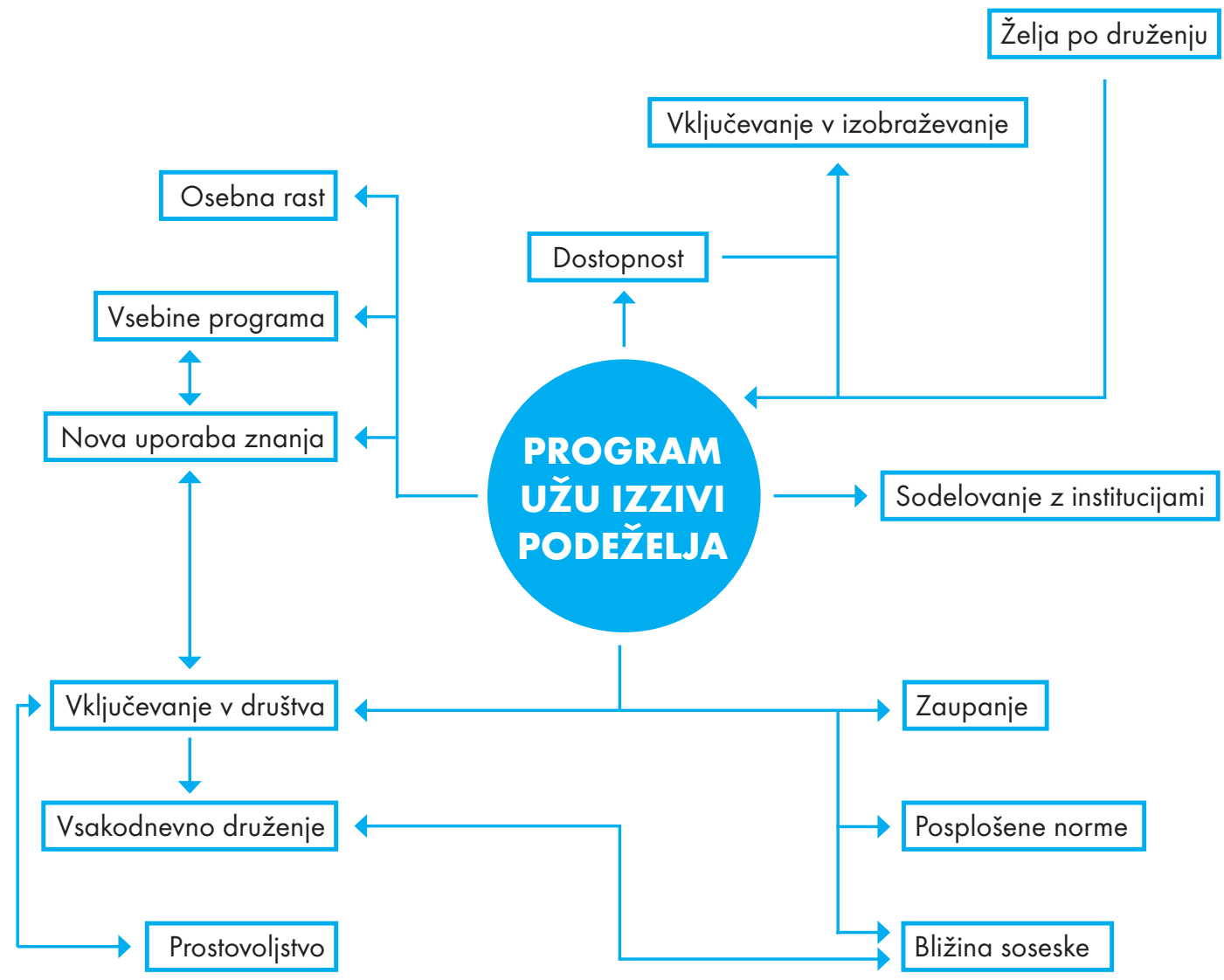


večinoma družijo z ljudmi iz ožjega sorodstva in ozkim krogom prijateljev.

Vprašani se večinoma ne vključujejo v izobraževalne programe za odrasle, razen nekateri, ki se občasno izobražujejo v krajših usposabljanjih za potrebe dela pri delodajal$\mathrm{cu}$. Kot razloge navajajo pomanjkanja interesa in časa ali pa ne vidijo potrebe po izobraževanju. Eden od vprašanih se je enkrat vključil v izobraževalni program za odrasle, vendar je po prvem srečanju izobraževanje opustil, ker se je počutil nesposobnega in je bil izpostavljen pred skupino. Slab občutek, ki ga je pri tem imel, je vplival na nadaljnje vključevanje v izobraževanje, saj se od takrat ni nikoli več vključil v kakršnokoli izobraževanje.

Intervjuvance smo spraševali tudi o tem, pod katerimi pogoji bi se vključili v izobraževanje. Kot pravijo, so zanje pomembne vsebine programa in pridobitev javnoveljavne formalne izobrazbe. Eden od vprašanih trdi: » $\check{C} e b i$ bile vsebine zanimive in bi me zanimale, $b i$ se vključil. Če me ne bi zanimalo, pa ne, ker nimam časa.«

Na odločitev o vključitvi v izobraževanje torej pomembno vplivajo vsebine programa.

Opazimo lahko tudi povezavo med vsakodnevnim druženjem in vključevanjem v izobraževanje. Eden od vprašanih pravi tako:

»Družba, druženje mi je pomembno. Sigurno, če bi mi prijatelji rekli, da gremo skupaj, bi se odločil za vključitev.«

Podobno razmišlja tudi oseba, ki trdi: »Jaz $b i$ šla, samo ne sama. Nimam pa nobenega sorodnega, ki bi ga zanimalo.«

Na vključevanje v izobraževanje pomembno vpliva tudi dostopnost, saj bi se vprašani veči- noma vključili v različna izobraževanja, če bi se izvajala $v$ njihovi vasi in bi bila brezplačna.

Ko smo intervjuvance spraševali o prostovoljnem delu, se je izkazalo, da večina od njih ne sodeluje pri prostovoljnem delu in tudi niso kritični do drugih ljudi, ki niso prostovoljci. Intervjuvanci menijo, da ljudje zelo različno prispevajo k skupnostnim dejavnostim v njihovi vasi. Pravijo, da se v vasi močno pričakuje, da bodo ljudje prostovoljno sodelovali pri skupnostnih dejavnostih, in to podpirajo. Poudarjajo pomen društev, ki spodbujajo prostovoljstvo na vasi, še posebno v zadnjem času. Opazna je tudi povezava med vključevanjem v prostovoljno delo ter članstvom v društvih in drugih organizacijah. Nihče od intervjuvancev ni dejaven član nobene organizacije, skupine, kluba ali društva in po večini vprašani tudi ne sodelujejo kot prostovoljci pri skupnostnih dejavnostih.

Opažamo tudi povezavo med vsakodnevnim druženjem, bližino soseske in zaupanjem ter posplošenimi normami. Vprašani se družijo z ljudmi, ki jim bolj zaupajo. Najvišje ocenjujejo zaupanje družini, izkazujejo tudi srednjo do močno povezanost soseske in visoko raven zaupanja do sovaščanov. Tako se vprašani v prostem času večinoma družijo z ožjim krogom prijateljev in bližnjimi sorodniki ter sosedi, $\mathrm{z}$ drugimi pa redkeje ali nikoli. Omenjajo pomanjkanje časa za druženje pa tudi nezaupanje: »Prostega časa je zmeraj manj, na račun zaupanja. Če bi bilo zaupanja več, bi se več družili.«

Vprašani izkazujejo tudi srednje močno do močno zaupanje državnim institucijam; policiji, sodišču, sodnikom, vladnim službam, občinski upravi. Zelo nizko raven zaupanja pa kažejo do politikov.

Odgovori na vprašanja o politični participaciji ne kažejo na povezave s preostalimi kategorijami. 
Z izjemo enega so se vsi vprašani udeležili državnozborskih in lokalnih volitev. Nihče pa ni sodeloval pri kakšnem protestu, popisal peticije ali kot kandidat nastopil na volitvah.

\section{PRIMERJAVA PODATKOV}

Med preučevanima skupinama udeležencev programa UŽU IP in oseb, ki niso bile vključene $\mathrm{v}$ program, obstajajo pomembne razlike, ki se nanašajo na posamezne elemente socialnega kapitala. $\mathrm{V}$ nekaterih elementih razlike niso tako izrazite ali pa jih sploh ni. V nadaljevanju bomo obravnavali predvsem značilne razlike med preučevanima skupinama, iz katerih lahko sklepamo na povezavo med izobraževanjem odraslih, v našem primeru izobraževalnim programom UŽU IP, in razvojem socialnega kapitala.

\section{Vključevanje v izobraževanje}

Inervjuvanci v obeh skupinah navajajo, da se v izobraževanje manj vključujejo oziroma se ne vključujejo zaradi pomanjkanja časa in zanimanja za izobraževanje. Intervjuvane osebe, ki niso bile vključene v program UŽU IP, se po večini sploh ne vključujejo v izobraževalne programe za odrasle, razen za potrebe dela na delovnem mestu. Eden od vprašanih, ki se je nekoč vključil v krajši program, je po prvem srečanju izobraževanje opustil zaradi občutka nesposobnosti. Udeleženci UŽU IP se pred sodelovanjem v programu UŽU IP po večini tudi niso vključevali $\mathrm{v}$ izobraževanje, razen nekateri, ki navajajo izobraževanje za potrebe dela ter krajše programe in seminarje, organizirane znotraj društev. Pri tej skupini je opazen vpliv programa UŽU IP na vključevanje v izobraževanje. Udeleženci so povedali, da so se po končanju programa UŽU IP vključili tudi v druge izobraževalne programe, pri čemer navajajo tako daljša usposabljanja kot tudi krajše tečaje in predavanja. Pri odločitvi za vključitev v izobraževanje oboji kot ključne dejavnike navajajo dostopnost in vsebine programa. Udeleženci UŽU IP, ki se udeležujejo izobraževanja, kot pomembna kriterija dodajajo še pridobitev uporabnih znanj in željo po druženju.

\section{Vključevanje $\mathbf{v}$ društva}

Osebe, ki so bile vključene v program UŽU IP, so bile večinoma včlanjene tudi v različna društva. Pri tem naštevajo društvo invalidov, oljkarsko društvo, društvo upokojencev, univerzo za tretje življenjsko obdobje, športno in kulturno društvo. Nasprotno pa nobena od vprašanih oseb, ki niso bile vključene v program UŽU IP, ni dejavna članica nobenega društva. Razlika pri vključevanju v društva se je izkazala kot zelo pomembna, saj članstvo v društvih lahko povežemo tudi s prostovoljstvom in vsakodnevnim druženjem. Člani društev so pogosto dejavni kot prostovoljci in se družijo s širšim krogom ljudi.

\section{Prostovoljstvo}

Izkazalo se je, da je za obe skupini značilno, da imata visoka pričakovanja glede prostovoljnega sodelovanja pri skupnostnih dejavnostih, vendar se odkrivajo izrazite razlike $\mathrm{v}$ njihovem mnenju o nesodelovanju. Medtem ko so udeleženci UŽU IP večinoma kritični do tistih, ki ne sodelujejo pri skupnostnih dejavnostih kot prostovoljci, pa so osebe, ki niso bile vključene v UŽU IP, večinoma bolj tolerantne.

Izrazite razlike se kažejo tudi pri sodelovanju intervjuvancev pri prostovoljnem delu. Medtem ko so vsi udeleženci UŽU IP tudi prostovoljci vsaj nekajkrat na leto, pa intervjuvane osebe, ki niso bile vključene v UŽU IP, po večini ne opravljajo prostovoljnega dela. 


\section{Vsakodnevno druženje}

Pomembne razlike med analiziranima skupinama se kažejo tudi pri vsakodnevnem druženju. Udeleženci programa UŽU IP se po večini družijo s širšim krogom prijateljev in družinskih članov, medtem ko se druženje oseb, ki niso bile vključene v UŽU IP, omejuje na ožji krog tesnejših prijateljstev in sorodstva.

\section{UGOTOVITVE RAZISKAVE}

Iz primerjave podatkov obeh skupin lahko ugotovimo, da med njima obstajajo pomembne razlike glede posameznih elementov obravnavanega koncepta, ki kažejo na povezave med programom UŽU IP in razvojem socialnega kapitala. Najpomembnejše razlike med skupinama se kažejo pri socialnih omrežjih in normah recipročnosti, medtem ko sta si glede zaupanja dokaj podobni.

\section{Zaupanje}

Pokazalo se je, da med preučevanima skupinama glede zaupanja ni velikih razlik, saj po večini intervjuvanci $\mathrm{v}$ obeh izkazujejo srednjo do močno raven zaupanja. Obe skupini izkazujeta visoko raven zaupanja do ljudi v krogu družine, dokaj visoko ocenjujeta tudi zaupanje do ljudi v isti vasi. Srednje do močno zaupanje izkazujejo tudi različnim skupinam: pripadnikom iste oziroma drugih verskih skupnosti, ljudem iste oziroma drugih narodnosti, občinski upravi, sodiščem, državnim ustanovam. Skupini sta si podobni tudi v tem, da izražata izrazito nezaupanje do politikov. Za obe skupini je značilno večje zaupanje krvnim sorodnikom kot ustanovam, kar je značilno predvsem za tradicionalne družbe $\mathrm{z}$ visoko razvito vezivno različico socialnega kapitala. Na to vrsto socialnega kapitala lahko sklepamo tudi iz pričevanj vprašanih o vplivu poznavanja ljudi na zaupanje. Ko razlikujemo zaupanje na različnih ravneh, lahko pri obeh skupinah ugotovimo dokaj visoko raven tako generaliziranega kot institucionalnega zaupanja. Obe skupini namreč izražata dokaj visoko zaupanje v ljudi na splošno, kar se nanaša na generalizirano zaupanje. Prav tako sta skupini srednje do močno zaupljivi do različnih državnih institucij, kar opredeljuje institucionalizirano zaupanje. Zaupanje politikom, ki je na najnižji stopnji, smo izvzeli, ker menimo, da je na oceno vprašanih vplival tudi čas izvajanja intervjujev, to pa je bil čas po državnozborskih volitvah, ko se koalicija še ni sestavila.

\section{Prostovoljstvo}

Osebe, ki niso bile vključene v program UŽU IP, po eni strani izražajo dokaj visoko raven zaupanja, sočasno pa so družbeno pasivne. To nikakor ne velja za skupino udeležencev programa UŽU IP. Pri primerjavi podatkov o prostovoljnem delu smo ugotovili, da med skupinama obstajajo pomembne razlike. Osebe, ki niso bile vključene $\mathrm{v}$ program UŽU IP, se večinoma ne vključujejo $\mathrm{v}$ prostovoljne dejavnosti, udeleženci programa UŽU IP pa so večinoma vsaj nekajkrat na leto dejavni tudi kot prostovoljci. Pri njih opazimo generalizirano recipročnost, ki ustvarja velik socialni kapital in podpira sodelovanje. Ponovno se je potrdilo tudi, da se v izobraževanje bolj vključujejo tisti, ki so tudi drugače družbeno dejavni.

Vendar pa moramo biti previdni in ne smemo zanemariti drugih vplivov na prostovoljstvo. Na vključevanje v družbene dejavnosti oziroma prostovoljno delo lahko pomembno vplivajo tudi drugi dejavniki, na tem mestu poudarjamo predvsem vključevanje $\mathrm{v}$ društva. Večinoma so bili namreč udeleženci UŽU IP že pred vključitvijo v program člani različnih društev. 
Presenetljivo za nas je, da so osebe, ki niso bile vključene v UŽU IP, tolerantnejše do tistih oseb, ki ne sodelujejo v skupnostnih dejavnostih in ne opravljajo prostovoljnega dela. Udeleženci UŽU IP so do njih predvsem kritični, iz česar bi lahko sklepali na premostitveni socialni kapital, saj se tu izrazito izkazuje funkcija družbenega nadzora.

\section{Socialna omrežja}

Med preučevanima skupinama se velike razlike razkrivajo še pri eni sestavini socialnega kapitala, tj. socialnih omrežjih. Za osebe, ki niso bile vključene v UŽU IP, je značilno, da se družijo z ožjim krogom tesnejših prijateljev in sorodnikov, kar nakazuje na vezivni socialni kapital, za katerega so značilne močne vezi. Nasprotno se udeleženci UŽU IP družijo s širšim krogom prijateljev in znancev, ki so jih spoznali v društvih in na izobraževanjih. Udeleženci UŽU IP so vključeni v različna društva, večina je članov več društev. Tu se izkazuje visoka raven premostitvenega socialnega kapitala, za katerega so značilne šibke vezi. Program UŽU IP je vplival na razvoj te različice socialnega kapitala s tem, da je udeležencem omogočil spoznavanje novih ljudi, to pa vpliva na širjenje socialnih omrežij. Ta omrežja vsebujejo veliko šibkih vezi, tako da sodelovanje ne predpostavlja visokih pričakovanj o naklonjenosti drugih, ampak je ključen interes, ki ljudi povezuje. Udeleženci programa UŽU IP so v programu skozi pozitivne izkušnje sodelovanja $\mathrm{z}$ drugimi razvili večje zaupanje in interes za nadaljnje sodelovanje, kar pozitivno vpliva na razvoj socialnega kapitala. S tem ko program UŽU IP spodbuja širjenje socialnih omrežij, krepi ustvarjanje premostitvenega socialnega kapitala.

Raziskovali smo tudi, kateri so tisti elementi programa UŽU IP, ki jih lahko povežemo z razvojem socialnega kapitala. Našli smo poveza- ve med razvojem socialnega kapitala in dostopnostjo programa, njegovimi vsebinami, ciljno skupino, ki ji je program namenjen, in sodelovanjem z institucijam. Ti elementi posredno vplivajo na razvoj socialnega kapitala, s tem ko vplivajo na vključenost v izobraževanje.

\section{Dostopnost programa}

Dostopnost se je izkazala kot izrazito pomembna pri odločitvi za vključitev $\mathrm{v}$ program. Program UŽU IP je bil za udeležence brezplačen in se je izvajal $v$ vaseh, torej blizu njihovega doma. $Z$ vidika dostopnosti se je pomembnejša kot brezplačnost pokazala izvedba programa na vasi, torej blizu njihovega doma. Dostop do nadaljnjega izobraževanja je udeležencem povečal možnosti sodelovanja in tudi dostop do uporabnih in koristnih informacij.

\section{Vsebine programa}

Pri odločitvi za vključitev v izobraževanje so udeleženci kot pomembne navedli tudi vsebine programa in pridobivanje uporabnih znanj. Naštevali so različne vsebine, poudarili pa tiste, pri katerih so pridobili uporabna znanja za vsakdanje življenje in delo na podeželju, npr. računalništvo, tuji jeziki, komunikacija. Pravijo, da jim pridobljena znanja lajšajo komunikacijo, pri čemer poudarjajo komuniciranje s pomočjo računalnika. Program UŽU IP je imel največji vpliv na tiste, ki se prej niso vključevali v izobraževanje. Ta vpliv se kaže predvsem $v$ osebnostni rasti. Udeleženci pravijo, da so postali bolj samozavestni, optimistični, odprti in da laže navezujejo stike z drugimi.

\section{Vključenost}

Program UŽU IP je pomembno vplival na vključevanje udeležencev v druge izobraževalne programe za odrasle. Tako se je večina 
vprašanih po programu UŽU IP kmalu udeležila različnih drugih neformalnih izobraževalnih programov za odrasle. Torej je spodbudil večjo vključenost in širjenje socialnih omrežij ter posledično omogočil višjo raven vezivnega socialnega kapitala.

Ciljna skupina za program so manj izobraženi odrasli prebivalci podeželja, za katere se med drugim pričakuje tudi primanjkovanje spretnosti v komunikaciji, iskanju in izbiri informacij ter na splošno pri dejavnem vključevanju v širšo družbeno skupnost. Program je torej namenjen deprivilegirani skupini, ki čuti mnoge ovire pri sodelovanju, vplivanju in soodločanju na vseh ravneh družbe, za katero se predvideva, da ji primanjkuje socialnega kapitala. Vključevanje v izobraževanje zmanjšuje socialno izključenost ter pripomore $\mathrm{k}$ doseganju tistih sprememb $\mathrm{v}$ odnosu in vedenju, ki spodbujajo socialni kapital.

\section{Sodelovanje $\mathrm{z}$ institucijami}

Opažamo tudi pozitiven vpliv programa na sodelovanje udeležencev z institucijami, pri čemer vprašani omenjajo predvsem ljudsko univerzo, ena oseba pa tudi knjižnico. Ljudska univerza je $\mathrm{v}$ našem primeru pomembna izobraževalna institucija, ki spodbuja ustvarjanje premostitvenega socialnega kapitala, saj zagotavlja prostor za druženje in krepi sodelovanje, njen vpliv pa se pomembno kaže v okolju, kjer deluje. Pomembno vlogo pri ohranjanju socialnih stikov na podeželju imajo tudi prostori krajevne skupnosti. Prostorske možnosti so eden od osnovnih pogojev za izvedbo programa $\mathrm{v}$ teh vaseh in s tem povečujejo dostopnost programa.

\section{SKLEPNE MISLI}

Z našo raziskavo smo potrdili, da vključevanje $\mathrm{v}$ neformalno izobraževanje odraslih pomembno vpliva na razvoj socialnega kapitala na podeželju. Pokazali smo, da izobraževanje pripomore $\mathrm{k}$ večjemu vključevanju $\mathrm{v}$ družbo in posledično $\mathrm{k}$ širjenju socialnih omrežij. S tem pomembno vpliva na zaupanje, posredno pa tudi na večjo družbeno dejavnost.

Zaradi večjega zaupanja se krepi tudi socialna vključenost. Ljudje se družijo s širšim krogom prijateljev in se ne zapirajo $\mathrm{v}$ krog sorodstva in lokalnih znancev, zaradi česar se povečuje premositveni socialni kapital. Še vedno pa se kaže tudi močan vezivni socialni kapital, predvsem v smislu družbenega nadzora, zaupanja, norm in solidarnosti. Govorimo lahko o sovplivanju in prepletanju vezivne in premostitvene različice socialnega kapitala. Prvo povezujemo predvsem s tem, da so ljudje na podeželju na splošno veliko bolj zavezani, veliko bolj »bonding «, torej manj »moderni « oz. »urbani«. Kljub izobraževanju in dejavnemu vključevanju v družbeno življenje še vedno ohranjajo tradicionalne družbene vzorce. Soobstoj prve in druge različice socialnega kapitala lahko razložimo tudi z nizko stopnjo urbanizacije slovenske družbe.

\section{LITERATURA IN VIRI}

Adam, F., Makarovič, M., Rončević, B., in Tomšič, M. (2001): Sociokulturni dejavniki razvojne uspešnosti: Slovenija v evropski perspektivi. Ljubljana: Znanstveno in publicistično središče.

Adam, F., Kump, S., Makarovič, M., Podmenik, D., Rončević, B., Tomšič, M, Vidovič, U. (2003):

Socialni kapital v Sloveniji. Ljubljana: Sophia.

Barbič, A. (2005): Izzivi in priložnosti podeželja.

Ljubljana: Fakulteta za družbene vede.

Coleman, S. J. (2000): »Social Capital in the

Creation of Human Capital«. V: Lesser, L. E.

(ur.), Knowledge and Social Capital: Foundations and Aplications. Boston. 
Dika, Sandra L., Singh, K. (2002): »Applications of Social Capital in Educational Literature: A Critical Synthesis «. Review of Educational Research, 1: 31-60.

Fukuyama, F. (1995): Trust: The Social Virtues and the Creation of Prosperity. London: Hamish Hamilton.

Gittel, R., Vidal, A. (1998): Community organizing: Building Social Capital as a Development Strategy. London, Tousand Oaks: Sage.

Izobraževalni program za odrasle: Usposabljanje za življenjsko uspešnost Izzivi podeželja (2005). Ljubljana: Ministrstvo za šolstvo in šport RS. Dostopno na: http://www.mss.gov.si/fileadmin/mss.gov.si/pageuploads/podrocje/odrasli/ Programi/Program_odrasli_uzu_ip.pdf (pridobljeno 12. 12. 2011).

Kovačič, M., Gosar, L., Fabijan, R., Perpar, T. (2000): Razvojno-tipološka členitev podeželja $v$ Republiki Sloveniji. Ljubljana: Biotehniška fakulteta, Oddelek za agronomijo, Inštitut za agrarno ekonomiko.

Kump, S. (2003): »Socialni kapital in izobraževanje odraslih«. V: Adam, F. in drugi, Socialni kapital v Sloveniji. Ljubljana.

Lenarčič, B. (2010): Socialni kapital v virtualnih skupnostih. Koper: Univerzitetna založba Annales.

Lin, N. (2001): Social Capital. A Theory of Social Structure and Action. Cambridge: University Press. Mermolja, E. (2012): Izobraževalni program UŽU Izzivi podeželja v luči socialnega kapitala. Magistrska naloga. Nova Gorica: Fakulteta za uporabne družbene študije.

Narayan, D., in Michael, C. (2001): »A Dimensional Approach to Measuring Social Capital: Development and Validation of a Social Capital Inventory«. Current sociology, 2: 59-102.

Pelc, S. (2002): »Geografija in celostni razvoj podeželja«. Dela, 18: 227-241.

Portes, A. (1998): »Social capital: Its Origins and Applications in Modern Sociology«. Annual Review of Sociology, 24: 1-24.

Potočnik Slavič, I. (2009): »Socialni kapital na slovenskem podeželju«. Razprave, 31: 21-24.
Putnam, R. (1995): Bowling alone: The Collapse and Revival of American Community. New York: Simon and Schuster.

Putnam, R. (2000): »Bowling alone: America's Declining Social Capital«. Journal of Democracy, 1: 65-78.

Rončević, B. (2003): »Socialni kapital in razvojne koalicije: Oblikovanje gospodarskih strategij in podjetniških grozdov v Sloveniji«. V: Adam, F. in drugi, Socialni kapital v Sloveniji. Ljubljana.

Tomšič, Matevž (2003): »Politika in socialni kapital«. V: Adam, F. in drugi, Socialni kapital v Sloveniji. Ljubljana.

Vehovar, U. (2009): »Vrednote prebivalstva Republike Slovenije in možnosti za nadaljnjo modernizacijo slovenske družbe - proces retradicionalizacije slovenske družbe kot dejavnik njene modernizacijske blokade«. Raziskave in razprave, 3: 3-39.

Vehovar, U., Makarovič, M., Podgornik, N., Černič, M. (2009): Od ekonomskega do kulturnega kapitala. Izobraževalni sistem kot dejavnik socialnega izključevanja $v$ Republiki Sloveniji. Ljubljana: Vega.

Wolfe, R. N. (1976). »Trust, anomie, and the locus of control: alienation of US college student in 1964, 1969, 1974«. Journal of Social Psychology, 1: 151-172.

Woolcock, M., Narayan, D. (2000): »Social Capital: Implications for Development Theory, Research, and Policy«. World Bank Research Observer, 2: $2-49$. 